\title{
Strategi Komunikasi Dinas Pariwisata Provinsi Nusa Tenggara Barat dalam Meningkatkan Kunjungan Wisatawan Lombok Sumbawa
}

tahun 2016 - 2017

\author{
Diana Juwita ${ }^{1}$, Siti Chotijah², Arifuddin Sahidu ${ }^{3}$ \\ 1. Program Studi Ilmu Komunikasi, Universitas Mataram \\ 2. Program Studi Ilmu Komunikasi, Universitas Mataram \\ 3. Program Studi Ilmu Komunikasi, Universitas Mataram
}

\begin{abstract}
Lombok Sumbawa has experienced rapid tourist growth in the last 5 years. The achievements obtained by Lombok Sumbawa in the increase of tourist visits in 2016 and 2017 are certainly the achievements made by the NTB Provincial Tourism Office on the programs implemented. This research is important because tourism in NTB is a sector that plays an important role in economic growth in NTB. The purpose of this study was to find out the Communication Strategy of the NTB Province Tourism Office in Increasing Visits of Lombok Sumbawa Tourists in 2016 - 2017.

This study used a descriptive method. The research was carried out at the NTB Provincial Tourism Office, with the main information sources being the Head of Market Analysis of the NTB Provincial Tourism Office.

The results showed that the NTB Provincial Tourism Office implemented a communication strategy in increasing Lombok Sumbawa tourism visits in 2016 - 2017. The communication strategy carried out by the NTB Provincial Tourism Office was (1) Collaboration on Penta Helix Synergy, (2) Events, and (3) Promotion. This communication strategy is able to increase tourists visiting Lombok Sumbawa in 2016 - 2017, which is 3,094,437 (1,690,109 domestic tourists, $1,404,328$ foreign tourists) in 2016, and 3,508,903 (2,078,654 domestic tourists, and 1,430,249
\end{abstract} foreign tourists in 2017.

\begin{abstract}
Abstrak
Lombok Sumbawa telah mengalami pertumbuhan wisatawan yang cukup pesat dalam 5 tahun terakhir. Pencapaian yang telah diperoleh oleh Lombok Sumbawa dalam peningkatan kunjungan wisatawan di tahun 2016 dan 2017 tentunya merupakan pencapaian yang dilaksanakan Dinas Pariwisata Provinsi NTB akan program - program yang dilaksanakan. Penelitian ini penting dilakukan karena pariwisata di NTB merupakan sektor yang sangat berperan dalam pertumbuhan ekonomi di NTB. Tujuan dari penelitian ini adalah Untuk mengetahui Strategi Komunikasi Dinas Pariwisata Provinsi NTB Dalam Meningkatkan Kunjungan Wisatawan Lombok Sumbawa tahun 2016 - 2017. Penelitian ini menggunakan metode deskriptif. Penelitian ini dilaksanakan di Dinas Pariwisata Provinsi NTB, dengan sumber informasi utama yaitu Kepala Analisa Pasar Dinas Pariwisata Provinsi NTB.

Hasil penelitian menunjukan bahwa Dinas Pariwisata Provinsi NTB melaksanakan strategi komunikasi dalam meningkatkan kunjungan wisata Lombok Sumbawa tahun 2016 2017. Strategi komunikasi yang dilakukan oleh Dinas Pariwisata Provinsi NTB yaitu, (1) Kerjasama Sinergi Penta Helix, (2) Event, dan (3) Promosi. Strategi komunikasi yang dijalankan ini mampu meningkatkan kunjungan wisatawan Lombok Sumbawa tahun 2016 - 2017, yaitu
\end{abstract}


sebanyak 3.094.437 (1.690.109 wisatawan nusantara, 1.404.328 wisatawan mancanegara) pada tahun 2016, dan 3.508.903 (2.078.654 wisatawan nusantara, dan 1.430.249 wisatawan mancanegara) pada tahun 2017.

\section{Pendahuluan}

Sektor pariwisata di Indonesia saat ini telah mengalami perkembangan yang cukup signifikan. Nusa Tenggara Barat (NTB) merupakan salah satu provinsi di Indonesia yang saat ini tengah menjadi sorotan para wisatawan, terdiri atas dua pulau besar yaitu, pulau Lombok dan pulau Sumbawa. Prestasi yang telah diraih oleh Provinsi NTB yaitu mendapatkan 4 (empat) kategori penghargaan dalam Kompetisi Pariwisata Halal Tingkat Nasional (KPHN) 2016, meliputi penghargaan dalam kategori Resort Ramah Wisatawan Muslim Terbaik, WebsiteTravel Ramah Wisatawan Muslim Terbaik, Destinasi Bulan Madu Ramah Wisatawan Muslim Terbaik, dan Kuliner Halal Khas Terbaik (Kementerian Pariwisata, 2016). Tidak hanya itu, pada tahun 2017, menurut Menteri Pariwisata Arif Yahya dalam kompas.com (17/03/2016), saat ini Lombok menjadi tujuan wisata di Indonesia kedua setelah Bali. Selain itu, ulasan situs Tripadvisor dalam cnnindonesia.com mengatakan bahwa Lombok berada di urutan ke-9 dari 24 kota yang masuk dalam nominasi sebagai Top Destinations in the World 2017, mengalahkan Tokyo, Jepang. Sedangkan Bali berada di peringkat pertama mengalahkan London, Paris, Roma, dan New York.

Jumlah wisatawan Lombok Sumbawa mengalami peningkatan pada tahun 2016,yaitu 3.094.437 orang wisatawan, dengan rincian wisatawan mancanegara sebanyak 1.404.328 orang dan 1.690.109 orang wisatawan nusantara yang mengunjungi Lombok Sumbawa (Dinas Pariwisataa NTB, 2017), sedangkan pencapaian kunjungan wisatawan pada tahun 2017 yakni sebanyak 3.508.903 wisatawan, yang merupakan akumulasi dari 2.078.654 wisatawan nusantara dan 1.430.249 wisatawan mancanegara, jumlah tersebut dikatakan melebihi target awal yaitu 3.500.000 wisatawan (Muhammad Faozal, 2017 cit. Nursyamsi, 2017). Peningkatan jumlah wisatawan Lombok Sumbawa merupakan suatu prestasi bagi Provinsi NTB dan sekaligus menjadi acuan untuk lebih meningkatkan kualitasnya dalam sektor pariwisata.Terlebih melihat potensi wisata Lombok Sumbawa yang masih banyak dan layak untuk dikembangkan.

Lombok Sumbawa telah mengalami perkembangan jumlah wisatawan yang cukup pesat dalam 5 tahun terakhir (Dinas Kebudayaan dan Pariwisata Provinsi NTB, 2016). Pencapaian yang telah diperoleh oleh Lombok Sumbawa dalam peningkatan kunjungan wisatawan di tahun 2016 tentunya merupakan pencapaian yang dilakukan Dinas Pariwisata Provinsi NTB akan program program yang telah ataupun masih dijalankan untuk mengusung brand pariwisata Lombok Sumbawa, dan mampu mengalahkan daerah - daerah di Indonesia lainnya yang bahkan pengembangan pariwisatanya sudah dilakukan lebih dulu. Dinas Pariwisata Provinsi NTB 
memiliki strategi komunikasi tertentu dalam mengkomunikasikan berbagai program pariwisata di NTB, sehingga Lombok Sumbawa layak dijadikan contoh bagi daerah di Indonesia dalam meningkatkan jumlah wisatawan, baik wisatawan nusantara, maupun wisatawan mancanegara.Selain hal tersebut penelitian ini penting dilakukan karena pariwisata di NTB merupakan sektor yang sangat berperan dalam pertumbuhan ekonomi, seperti yang disampaikan oleh Badan Pusat Statistik NTB bahwa pariwisata merupakan sektor yang sangat berperan dalam mendongkrak pertumbuhan ekonomi di NTB, terlihat dari pertumbuhan ekonomi Provinsi NTB sepanjang triwulan II tahun 2017 tumbuh 6,00\% (Nur, 2017). Strategi komunikasi terkait dengan persoalan bagaimana kebijakan dalam pelaksanaannya, penentuan tujuan yang ingin dicapai, langkah untuk mencapai tujuan tersebut, dan sarana penunjang/fasilitas. Oleh karena itu, dalam sebuah strategi komunikasi juga harus didukung oleh kemampuan untuk melihat peluang yang ada. Dalam melaksanakan fungsi dan peranannya dalam pengembangan pariwisata daerah, pemerintah daerah harus melakukan berbagai upaya dalam pengembangan sarana dan prasarana pariwisata, sehingga penelitian ini menjadi penting untuk membahas strategi komunikasi yang telah dilakukan oleh Dinas Parwisata NTB, dengan harapan ketika strategi yang sudah ada bisa dikembangkan, dan pariwisata NTB bisa berkembang lebih baik lagi.

Cara terbaik untuk melakuan sebuah kegiatan komunikasi adalah dengan menjawab pertanyaan "Who says what in which channel to whom and with what effect?" yang merupakan formula komunikasi yang disampaikan oleh Harold D Lasswell (Cangara, 2011). Berdasarkan formula dari Lasswell tersebut maka untuk menentukan sebuah strategi komunikasi akan selalu terkait dengan elemen tersebut. Dalam melakukan sebuah strategi komunikasi harus diawali dengan langkah - langkah berikut (Arifin, 2004 cit. Mahrik, 2016):

a. Pengenalan Khalayak

Khalayak merupakan salah satu aspek yang memiliki kekuatan penting dalam strategi komunikasi, karena khalayak merupakan sasaran yang akan dituju dalam sebuah strategi komunikasi. Dalam suatu strategi komunikasi khalayak memiliki semacam penangkal yang bersifat psikologis dan sosial. Yang dimaksudkan adalah individu/kelompok akan sulit menerima hal - hal yang baru atau berbeda dengan diri atau kelompoknya. Selain adanya faktor tersebut, akan ada banyak komunikator lain yang memberi informasi dalam waktu bersamaan. Oleh karena itu perlu dilakukannya pengenalan khalayak sebelum melakukan langkah selanjutnya, agar mampu mempersuasi/memecahkan penangkal tersebut agar pesan yang disampaikan dapat diterima dengan baik dan mengalahkan pengaruh pengaruh pesan yang bersumber dari komunikator lain.

b. Penyusunan Pesan 
Langkah selanjutnya dalam strategi komunikasi adalah penyusunan pesan.Pesan yang disusun harus mampu menarik perhatian khalayak sasarannya, karena untuk mendapatkan komunikasi yang efektif, menarik perhatian adalah kunci awal untuk mempengaruhi khalayak. Wilbur

c. Penetapan Metode

Menurut Arifin (2004) cit. Mahrik (2016) teknik penyampaian pesan dalam komunikasi dapat dilihat melalui 2 aspek yaitu, menurut cara pelaksanaan dan menurut bentuk isinya, dengan penjelasan sebagai berikut:

1. Menurut cara pelaksanaan, yaitu melihat komunikasi dari segi pelaksanaannya, tanpa memperhatikan isi pesan komunikasi tersebut. Berikut adalah metode/teknik penyampaian pesan menurut cara pelaksanaannya:

a) Redundancy (repetition), adalah penyampaian pesan yang dilakukan secara berulang ulang kepada khalayak, dengan teknik ini khalayak akan lebih mudah menarik perhatian khalayak.

b) Canalizing adalah memahami dan meneliti pengaruh kelompok terhadap individu atau kelompok. Oleh karena itu pesan yang disampaikan harus memenuhi nilai dan standar dari kelompok dan masyarakat, sehingga secara perlahan dapat diarahkan sesuai dengan yang diinginkan oleh komunikator.

2. Menurut bentuk isinya, yaitu melihat komunikasi berdasarkan isi (bentuk dan makna) pesan itu sendiri. Berikut adalah metode/teknik penyampaian pesan menurut isinya:

a) Informatif, teknik ini digunakan untuk memberikan informasi secara apa adanya, fakta yang terjadi berdasarkan data - data dan opini yang benar.

b) Persuasif, yakni membujuk khalayak dengan menggugah pikiran hingga perasaan khalayak, karena itu perlu adanya kemampuan dari komunikan untuk dapat memberikan sugesti kepada khalayak agar mudah untuk dibujuk.

c) Edukatif, yaitu menyampaikan pesan yang mendidik berupa fakta - fakta, ilmu, dan lainnya sebagai salah satu usaha mempengaruhi khalayak berdasarkan pernyataan umum yang dilontarkan.

d) Koersif, adalah teknik penyampaian pesan dengan jalan cenderung "memaksa", biasanya dilakukan melalui peraturan - peraturan pemerintah, institusi dan lainnya.

\section{d. Penggunaan Media.}

Langkah akhir dalam melakukan sebuah strategi komunikasi adalah penggunaan media. Media digunakan sebagai saluran untuk menyampaikan pesan kepada khalayak. Media yang digunakan harus sesuai dengan karakteristik pesan yang ingin disampaikan dan khalayak yang 
akan dituju. Untuk khalayak yang lebih luas, media yang digunakan dalam penyampaian pesan sebaiknya menggunakan media massa, seperti surat kabar, televisi, dan sosial media, sedangkan untuk komunitas tertentu digunakan media selebaran atau salauran komunikasi yang digunakan oleh kelompok/komunitas tersebut.

Pengertian strategi komunikasi sendiri merupakan kolaborasi antara perencanaan komunikasi (communication planing) dengan manejemen komunikasi (communication management) untuk mencapai tujuan yang telah ditetapkan dengan menunjukan kegiatan operasionalnya secara praktis dan situasional (David, 2002). Onong Uchjana Effendy mengatakan bahwa inti dari strategi komunikasi adalah perencanaan dan manajemen komunikasi yang dilakukan untuk mencapai suatu tujuan spesifik yang dicapai hanya dengan taktik operasional (Ambar, 2017).

Bank Dunia (2001) cit. Efrita (2015) menjelaskan definisi strategi komunikasi sebagai berikut:

1. Strategi yang mengartikulasikan, menjelaskan, dan mempromosikan suatu visi komunikasi dan satuan tujuan komunikasi dalam rumusan yang baik.

2. Strategi untuk menciptakan komunikasi yang konsisten, komunikasi yang didasari oleh satu pilihan (keputusan) dari beberapa opsi komunikasi.

3. Strategi berbeda dengan taktik. Strategi komunikasi menjelaskan tahap konkrit dalam rangkaian aktivitas komunikasi yang berasas pada satuan taktik dari pengimplementasian tujuan komunikasi. Adapun taktik adalah satu pilihan tindakan komunikasi tertentu berdasarkan strategi yang telah ditetapkan sebelumnya.

4. Adalah akhir tujuan komunikasi, strategi berperan memfasilitasi perubahan prilaku untuk mencapai tujuan komunikasi manajemen.

\subsubsection{Fungsi dan Tujuan Strategi Komunikasi}

Dalam kegiatan komunikasi apapun, mulai dari komunikasi interpersonal, hingga komunikasi massa tentunya memerlukan strategi yang baik untuk mencapai respon yang diinginkan. Fungsi strategi komunikasi, jika dilihat secara makro (planed multimedia strategy) maupun mikro (single communication medium strategy)(Effendy, 2004) adalah sebagai berikut:

1. Menyebarkan pesan secara luas kepada khalayak atau sasaran, pesan yang disampaikan dapat bersifat informatif, persuasif, dan instruktif secara sistematis.

2. Sebagai jembatan akan "kesenjangan budaya" (social gap) yang disebabkan oleh kemudahan akses dan penggunaan informasi di media massa, yang jika dibiarkan akan berbahaya bagi nilai - nilai budaya yang ada. 
R. Wayne Peace, Brent D. Peterson, dan M. Dallas Burnett mengatakan bahwa, tujuan dari strategi komunikasi adalah (Effendy, 2007):

1. To secure understanding

2. To establish acceptance

3. To motivate action

Menurut Efrita (2015), strategi komunikasi memiliki 3(tiga) esensi utama yaitu, strategi implementasi, strategi dukungan, dan strategi integrasi. Pelaksanaan strategi komunikasi diuraikan dengan langkah - langkah sebagai berikut:

1. Mengidentifikasi visi dan misi. Visi merupakan cita - cita ideal jangka panjang yang dapat dicapai oleh komunikasi. Rumusan visi biasanya terdiri dari "beberapa kata" yang mengandung tujuan, harapan, cita - cita ideal komunikasi. Dari rumusan visi itulah akan dirumuskan misi yang menjabarkan cita - cita ideal komunikasi.

2. Menentukan program dan kegiatan. Pogram dan kegiatan adalah serangkaian aktivitas yang harus dikerjakan, program dan kegiatan merupakan penjabaran dari misi.

3. Menentukan tujuan dan hasil. Setiap program atau kegiatan biasanya mempunyai tujuan dan hasil yang akan diperoleh. Biasanya para perumus kegiatan membuat definisi tentang tujuan dan hasil yang akan dicapai.

4. Seleksi audiens yang menjadi sasaran. Perencanaan komunikasi menentukan kategori audiens yang menjadi sasaran komunikasi.

5. Mengembangkan pesan. Kriterianya adalah semua pesan yang dirancang sedapat mungkin memiliki isi (content) khusus, jelas, persuasif, dan merefleksikan nilai-nilai audiens, tampilan isi yang dapat memberikan solusi bagi masyarakat, atau menunjukkan tindakan tertentu.

6. Identifikasi pembawa pesan (tampilan komunikator). Kriteria komunikator antara lain kredibilitas, kredibilitas dalam ilmu pengetahuan, keahlian, professional, dan keterampilan yang berkaitan dengan isu tertentu.

7. Mekanisme komunikasi/media. Kriterianya adalah memilih media yang tepat memperlancar mekanisme pengiriman dan pengiriman balik, atau pertukaran informasi. Kriteria media adalah media yang mudah diakses atau yang paling disukai audiens, misalnya melalui radio, koran kampung, dan leaflet.

8. Scan konteks dan persaingan. Kriterianya adalah menghitung resiko dan konteks yang akan mempengaruhi strategi komunikasi, misalnya menghitung peluang untuk memenangkan persaingan, dengan merebut hati audiens.

Kegiatan berikutnya adalah implementasi strategi melalui lima tahapan/jenis kegiatan (Efrita, 2015) yaitu: 
a. Mengembangkan materi untuk mengimplementasikan strategi.

b. Mengembangkan mitra yang bernilai.

c. Melatih para pembawa atau para penyebar pesan .

d. Mengembangkan semacam tata aturan bagi kegiatan penyebarluasan informasi kepada audiens misalnya melalui pemantauan, dan evaluasi implementasi.

e. Mengontrol setiap tahapan/jenis kegiatan melalui kriteria dan strandar yang ada.

Pada bagian akhir dari strategi komunikasi organisasi tersebut terdiri dari empat tahapan/ jenis kegiatan (Efrita, 2015) yaitu:

a. Mendukung komunikasi terutama pada level kepemimpinan.

b. Melengkapi sumber daya.

c. Mengintegrasikan komunikasi melalui organisasi.

d. Melibatkan staf pada semua level untuk memberikan dukungan dan integrasi (keempat tahap/jenis kegiatan tersebut dapat dikontrol melalui kriteria dan standar yang ada)

Prinsip - prinsip praktis strategi komunikasi yang disampaikan oleh Hewait Asociates, Shell Tower-times Square , Causeway, Hongkong (2009)cit. Efrita (2015), sebagai berikut:

a. Integrate, yakni proses penggabungan berbagai kegiatan terkait dengan satu program komunikasi.

b. Straightforward, katakan ini pada semua orang, kejujuran menyertai perjalanan kita/ honesty goes a long way. Inilah perjuangan masa depan.

c. Succinct, pesan strategis yang biasanya pendek dan sederhana.

d. Target segmen, tetapkan segmen yang akan menjadi sasaran.

e. Personalia, membantu pekerja agar memahami dampak personal.

f. Memorable, membuat ukuran dari hasil komunikasi yang akan dilakukan.

g. Multimedia, menggunakan metode dan media yang berfariasi.

h. Be realistic, bersikap realistis.

i. Be result, orientasikan kerja pada komunikasi yang dapat diukur.

Selain prinsip - prinsip praktis dalam strategi komunikasi, diperlukan komunikasi efektif untuk mendukung keberhasilan suatu strategi komunikasi. Berikut langkah - langkah perencanaan komunikasi (Efrita, 2015):

a. Analisis isu dan peranan komunikasi.

b. Seleksi kelompok sasaran/audiens dan stakeholders.

c. Menentukan target komunikasi.

d. Mengembangkan strategi dan seleksi mitra.

e. Menentukan pesan. 
f. Seleksi tujuan terutama komunikasi.

g. Mengorganisasikan komunikasi melalui pertemuan pertama dengan mitra.

h. Perencanaan kegiatan.

i. Akitivitas penganggaran.

j. Pemantauan dan evaluasi.

\section{Komunikasi Pemasaran Pariwisata}

Menurut Terence A. Shimp, komunikasi pemasaran merupakan interpretasi gabungan dari semua elemen bauran pemasaran atau marketing mix dengan memberikan fasilitas adanya pertukaran dengan menciptakan suatu arti yang disebarkan kepada pelanggan atau kliennya (Priansa, 2017). Uyung Sulaksana (2005) cit.Priansa(2017) menyatakan bahwa komunikasi pemasaran adalah sebuah proses penyebaran informasi terkait dengan hal - hal yang ingin ditawarkan oleh perusahaan kepada sasarannya. Komunikasi pemasaran merupakan aktivitas pemasaran yang bertujuan untuk menyebarkan infromasi, mempersuasi, dan mengingatkan pasar dari perusahaan itu sendiri terhadap produknya agar menerima, membeli, dan loyal terhadap produk yang ditawarkan perusahaan (Tjiptono, 2011 cit. Priansa, 2017).

Pengertian pariwisata secara umum, yaitu merupakan suatu kegiatan perjalanan yang dilakukan seseorang/kelompok dalam kurun waktu tertentu dari satu tempat ke tempat yang lain dengan tujuan ingin berlibur, atau semacamnya namun tidak dilakukan untuk mencari nafkah.

Efrita (2015) mengatakan bahwa pariwisata terkait dengan : Kegiatan orang-orang yang bepergian dari daerah wisatawan pergi ke daerah lain untuk mengisi waktu senggang dan untuk besenang-senang atau rekreasi yang sifatnya sementara waktu dan tidak menghasilkan di daerah tujuan wisata. Kegiatan pariwisata mengandung tiga unsur penting yaitu :1) Manusia (Man), yaitu orang yang melakukan perjalanan wisata yang disebut dengan wisatawan 2) Ruang (Space), yaitu daerah atau ruang lingkup tempat melakukan perjalanan dan 3) Waktu (Time) yaitu waktu yang digunakan selama dalam perjalanan dan tinggal di daerah tujuan wisata.

\section{Sinergi Penta Helix}

Sinergi Penta Helix merupakan sebuah pengembangan ekonomi sosial yang menggerakan pengetahuan ekonomi untuk mengejar sebuah tujuan dan kewirausahaan melalui kolaborasi dan kerjasama menguntungkan antara akademisi, pemerintahan, industri, NGO dan masyarakat sipil, serta pengusaha (REPEC, 2012 cit. Halibas, 2017). Model Penta Helix berakar dari model Triple Helix Etzkowitz dan Layersdorff's, dimana jaringan tri lateral berasal dari akademisi, industri, dan pemerintahan yang bergabung untuk mengambil keuntungan dari proyek penelitian yang inovatif yang dibudayakan dalam institusi pendidikan, dan menjadikan proyek ini dapat digunakan untuk produk atau jasa komersil. NGO, masyarakat sipil, dan pengusaha ditambahkan 
ke dalam penta helix. Mereka memiliki peran yang sangat penting dalam mendukung tujuan inovasi bersama dan mereka berkontribusi dalam pengembangan sosial ekonomi daerah (Rampersad, Quester, \& Troshani, 2010 cit. Halibas, 2017). Von Stamm (2004) cit. Halibas (2017) menyatakan bahwa inovasi sangat mudah dicapai ketika adanya kolaborasi yang kuat dan kerjasama diantara orang penting.

Sedangkan penta helix (Lindmark, Sturesson \& Roos, 2009cit.Wagiran, 2012) merupakan perluasan dari strategi triple helix dengan melibatkan berbagai unsur masyarakat maupun lembaga-lembaga non profit dalam rangka mewujudkan sebuah tujuan. Melalui kolaborasi sinergis tersebut diharapkan terwujud suatu inovasi yang didukung oleh berbagai sumberdaya yang berinteraksi secara sinergis.

Penta helix dalam pariwisata Indonesia dikenal dengan istilah Sinergi Penta Helix ABCGM, yang merupakan singkatan dari Academic, Business, Community, Government, Media (KEMENPAR dalam Laporan Capaian Sektor Pariwisata 3 Tahun Jokowi - JK).

\section{Event}

Event dalam arti sempit diartikan sebagai pameran,pertunjukan atau festival, dengan syarat ada penyelenggara, peserta dan pengunjung. Namun dalam arti luas, event diartikan sebagai suatu kurun waktu kegiatan yang dilakukan oleh sebuah organisasi dengan mendatangkan orang - orang ke suatu tempat agar mereka memperoleh informasi atau pengalaman penting serta tujuan lain yang diharapkan oleh penyelenggara (Kennedy, 2009 cit. Rahma, 2017).

Menurut Noor (2009) cit. Rahma (2017) Event adalah suatu kegiatan yang diselenggarakan untuk memperingati hal-hal penting sepanjang hidup manusia baik secara individu atau kelompok yang terikat secara adat, budaya, tradisi dan agama yang diselenggarakan untuk tujuan tertentu serta melibatkan lingkungan masyarakat yang diselenggarakan pada waktu tertentu.

\section{Promosi}

Promosi adalah kegiatan yang dilakukan untuk memperkenalkan suatu barang atau jasa agar konsumen tertarik untuk membelinya (Meidila, 2014). Menurut Kotler (2003) cit. Lestari(2015), promosi merupakan sebuah upaya yang dilakukan oleh perusahaan untuk mengkomunikasikan pesan - pesan yang dibuat untuk memicu terjadinya kesadaran (awareness), ketertarikan (interest), dan tindakan pembelian (purchase) terhadap barang atau jasa yang ditawarkan perusahaan. Promosi dalam kajian pemasaran merupakan suatu kegiatan dalam upaya menyadarkan customer terhadap produk dari suatu perusahaan.Dalam promosi pariwisata yang dilakukan pun adalah memberitahukan, membujuk atau meningkatkan minat wisatawan selaku konsumen untuk datang berkunjung ke daerah yang di promosikan. 


\section{Metode}

Penelitian ini menggunakan metode deskriptif, dengan obyek strategi komunikasi Dinas Pariwisata Provinsi NTB dalam meningkatkan kunjungan wisatawan Lombok Sumbawa tahun 2016 2017. Isaac, dan Michael cit. Rakhmat (2012) mengatakan bahwa metode deskriptif adalah metode penelitian yang bertujuan untuk melukiskan secara sistematis fakta atau karakteristik populasi atau bidang tertentu secara faktual dan cermat.

\section{Teknik Pengumpulan Data}

a. Observasi

Penulis turun ke lapangan untuk mengamati strategi komunikasi yang dilakukan oleh Dinas Pariwisata Provinsi NTB dengan melakukan observasi terus- terang atau tersamar, yaitu peneliti dalam melakukan pengumpulan data menyatakan terus terang kepada sumber data, bahwa sedang melakukan penelitian (Sugiyono, 2017). Oberservasi penting dilakukan untuk menguatkan kinerja yang dilakukan oleh Dinas Pariwisata Provinsi NTB pada tahun 2016 - 2017.

b. Wawancara

Penulis memilih 3 (tiga) informan yang berkompetensi di bidangnya untuk melakukan wawancara tatap muka, menggunakan pedoman wawancara yang telah dibuat untuk memperoleh data atau informasi yang lebih mendalam. Berikut adalah 3 (tiga) informan yang menjadi Narasumber dalam penelitian ini:

1. Kepala Seksi Analisa Pasar Dispar NTB (H. Abdul Haris)

2. Staf Analisa Pasar Dispar NTB (Medianto Idris)

3. Koordinator GenPI Lombok Sumbawa (Mala Mardiana)

c. Dokumentasi

Dokumentasi merupakan teknik pelengkap dari penggunaan metode observasi dan wawancara (Sugiyono, 2017). Dokumen dapat berupa laporan lembaga terkait, majalah, berita surat kabar, dan lainnya yang terkait dengan masalah yang diteliti. Dalam penelitian ini penulis memproleh dokumen dari Dinas Pariwisata Provinsi NTB berupa:

1. Buku Kajian Analisa Pasar Dinas Pariwisata Provinsi NTB 2016

2. Buku Statistik Kebudayaan dan Pariwisata

3. Website Dinas Pariwisata Provinsi NTB 


\section{Hasil dan Pembahasan}

Setelah melakukan penelitian lapangan selama kurang lebih 2 bulan, dengan melakukan observasi ke Dinas Pariwisata Provinsi NTB, wawancara dengan 2 Narasumber di Bidang Pemasaran Dinas Pariwisata Provinsi NTB, dan 1 Narasumber Koordinator GenPI, serta beberapa data sekunder berupa dokumen yang terkait dengan masalah yang diteliti, maka peneliti menyampaikan hasil penelitian tentang Strategi Komunikasi Dinas Pariwisata Provinsi NTB dalam Meningatkan Kunjungan Wisatawan Lombok Sumbawa pada tahun 2016 -2017.

Strategi komunikasi Dinas Pariwisata Provinsi NTB penting dilakukan, karena dalam pengembangan sebuah pariwisata perlu adanya strategi yang tepat. Seperti yang diungkapkan oleh Kepala Seksi Analisa Pasar Dinas Pariwisata Provinsi NTB, bahwa:

"Strategi tersebut sangat penting, untuk melakukan sebuah marketing dan promosi, karena tanpa adanya sebuah strategi kita akan tertinggal dari daerah - daerah lain yang tentunya memiliki strategi komunikasi tersendiri, sehingga NTB juga harus memiliki strategi. Ada beberapa hal yang harus kita perhatikan dalam melakukan sebuah strategi, yaitu dengan menjalin kerjasama dengan berbagai pihak seperti industri, media, dan komunitas untuk memajukan pariwisata NTB. Karena untuk mencapai hasil dari strategi yang baik kita tidak bisa bergerak sendiri”

Berdasarkan penjelasan Kepala Seksi Analisa Pasar Dinas Pariwisata Provinsi NTB, dalam meningkatkan kunjungan wisatawan Lombok Sumbawa tahun 2016 - 2017 Dinas Pariwisata Provinsi NTB telah melakukan strategi komuniksi. Berdasarkan hasil yang diperoleh, Dinas Pariwisata Provinsi NTB melaksanakan strategi komunikasi, dengan tujuan meningkatkan kunjungan wisatawan Lombok Sumbawa tahun 2016 - 2017. Tujuan tersebut sudah tercapai, bahkan melampaui target yang ditentukan. Hal tersebut sesuai dengan pengertian stategi komunikasi yaitu kolaborasi antara perencanaan komunikasi (communication planing) dengan manejemen komunikasi (communication management) untuk mencapai tujuan yang telah ditetapkan dengan menunjukan kegiatan operasionalnya secara praktis dan situasional (David, 2002). Berikut adalah strategi komunikasi yang dilakukan oleh Dinas Pariwisata Provinsi NTB:

Sinergi Penta Helix

Dinas Pariwisata Provinsi NTB menjalin kerjasama pariwisata dengan berbagai pihak terkait, yang dalam dunia pariwisata disebut dengan Sinergi Penta Helix yaitu kolaborasi atau kerjasama antar stakeholders yang terdiri dari akademisi, business/industri, community, government, dan media. Kerjasama pariwisata tersebut terbagi menjadi 5 bagian kerjasama, sebagai berikut:

a. Akademisi

Perkembangan pariwisata NTB tidak lepas dari peran para akademisi. Para Akademisi berperan dalam mencetak Sumber Daya Manusia (SDM) yang berkualitas di bidang pariwisata, untuk ikut meningkatkan pariwisata di NTB. Dinas Pariwisata Provinsi NTB merangkul para akademisi, lembaga 
pendidikan, sekolah dan universitas yang memiliki potensi di bidang pariwisata untuk menjadi SDM yang profesional di bidang pariwisata. Dinas Pariwisata Provinsi NTB mejalin kerjasama dengan akademisi New Zealand "Zitized", berupa riset tentang formulasi perhitungan data kunjungan wisatawan (statistik) yang dapat memudahkan Dinas Pariwisata Provinsi NTB dalam melakukan perhitungan kunjungan wisatawan.

Bentuk kerjasama lainya yang dilakukan oleh Dinas Pariwisata Provinsi NTB dengan sekolah maupun universitas adalah melibatkan sekolah - sekolah, dan Universitas dalam kegiatan budaya seperti dalam event Bulan Pesona Lombok Sumbawa, dengan mengajak siswa - siswa dan mahasiswa menjadi peserta parade/pawai, kemudian melibatkan mereka sebagai pengisi acara (gendang beleq, tari tradisional, perkusi). Selain hal tersebut Dinas Pariwisata Provinsi NTB juga mendukung kegiatan - kegiatan mahasiswa yang berkaitan dengan kebudayaan dan pariwisata, seperti menjadi sponsor utama dalam kegiatan Workshop film yang diadakan oleh Mahasiswa Ilmu Komunikasi Universitas Mataram pada tahun 2017 yang dirangkaikan dalam kegiatan Festival Bulan Pesona Budaya, kemudian mendukung kegiatan Mahasiswa KKN Universitas Mataram di Desa Perigi dalam mengadakan festival adat Limbungan pada September tahun 2017. Kepala Seksi Analisa Pasar Dinas Pariwisata Provinsi NTB mengatakan bahwa:

"Peran akademisi tidak bisa jauh dengan perkembangan pariwisata NTB, karena terkait dengan

SDM, karena sukses tidaknya tergantung pada SDM yang dimiliki. Kerjasama yang dilakukan pun

beragam, berupa sosialisasi, dan pelatihan - pelatihan pariwisata di sekolah dan universitas yang memiliki jurusan atau minat pada pariwisata."

b. Business/Industri

Industri memiliki peranan tersendiri dalam peningkatan pariwisata NTB. ASITA (Association of the Indonesian Tours and Travel Agencies) adalah suatu perkumpulan yang mewadahi pengusaha atau pelaku usaha di bidang jasa perjalanan wisata di Indonesia. ASITA menjadi mitra Dinas Pariwisata Provinsi NTB dalam mempromosikan pariwisata NTB. Bentuk kerjasama Dinas Pariwisata Provinsi NTB dengan ASITA adalah penyusunan produk paket wisata yang disesuaikan dengan program promosi prioritas, contohnya launching paket wisata halal. Namun, secara teknis dalam mengemas produk wisata disusun sepenuhnya oleh ASITA, dan dipasarkan kepada segmen pasar ASITA baik itu segmen pasar nusantara hingga mancanegara, karena ASITA bersifat independent. ASITA juga berperan mengkoordinasikan program dan produk dengan member ASITA sendiri (Travel Agent). Kepala Seksi Analisa Pasar mengatakan bahwa:

"Dinas Pariwisata bekerjasama dengan ASITA dalam promosi, dimana ranah ASITA adalah dalam penjualan paket - paket wisata yang mereka kemas sedemikian rupa dan secara teknis untuk 
ekesekusinya ASITA sendiri yang menentukan, karena ASITA bersifat independent dan mencari profit, sedangkan Dinas Pariwisata adalah pemerintahan dan non profit"

Tak hanya dengan ASITA, Dinas Pariwisata Provinsi NTB juga menjalin kerjasama dengan PHRI (Perhimpunan Hotel dan Restoran Indonesia) yaitu organisasi yang menaungi para pelaku industri hotel dan restoran yang menjadi anggota di dalamnya. PHRI berperan mengkoordinasikan program dan produk dengan member PHRI sendiri (Hotel dan Restoran). Kerjasama dengan PHRI tidak jauh berbeda dengan ASITA, yaitu mensinergikan program, dan produk wisata yang dipasarkan kepada wisatawan, dari paket wisata, harga penginapan, hingga kuliner, dengan tujuan hal tersebut dapat menjadi daya tarik dan memberikan kenyamanan bagi wisatawan.

Selain dengan ASITA, dan PHRI, Dinas Pariwisata Provinsi NTB juga menjalin kerjasama dengan Asosiasi Pelaku Pariwisata Indonesia (ASPPI) NTB dalam Pelaksanaan kegiatan International Halal Travel Fair (IHTF) II 2017. ASPPI NTB berperan sebagai pelaksana teknis kegiatan, dan mempertemukan buyers dengan para seller yang berasal dari ASPPI, ASITA, dan Asosiasi Pariwisata Islami Indonesia (APII) NTB.

Dinas Pariwisata Provinsi Provinsi NTB juga menjalin kerjasama dengan maskapai penerbangan yang memiliki askes perjalanan ke Lombok. Seperti Garuda Indonesia, Citilink, Lion Air, hingga maskapai dari mancanegara. Bentuk kerjasama yang dilakukan adalah pengadaan inflight magazine hingga video promosi tentang potensi pariwisata yang ada di Lombok dan Sumbawa. Inflight magazine merupakan bagian dari kesepakatan Dinas Pariwisata Provinsi NTB untuk mempromosikan pariwisata Lombok Sumbawa, Inflight magazine sebagian besar tidak berbayar. Sedangkan video promosi pariwisata ditayangkan pada saat pesawat akan landing, dengan sistem berbayar. Kepala Seksi Analisa Pasar mengatakan bahwa:

“Kerjasama yang dilakukan Dinas Pariwisata Provinsi NTB dengan maskapai - maskapai adalah memberikan kemudahan kepada beberapa maskapai untuk melakukan promosi melalui program famtour atau famtrip, baik itu media cetak ataupun elektronik yang hasilnya dipasarkan ke daerah famtour atau famtrip yang menjadi target pasar. Sehingga bentuk promosi yang telah dilakukan hasilnya berbentuk inflight magazine dan video promosi singkat tentang Lombok Sumbawa"

c. Community/Komunitas

Community atau komunitas merupakan salah satu yang berperan penting dalam perkembangan pariwisata di Nusa Tenggara Barat. Kepala Seksi Analisa Pasar Dinas Pariwisata Provinsi NTB mengatakan bahwa:

"Dalam tataran kabupaten/kota Dispar NTB membentuk beberapa kelompok sadar wisata atau biasa disingkat dengan "Pokdarwis" yang berperan dalam kegiatan pariwisata di daerahnya masing masing. Selain Pokdarwis, Dispar NTB juga bekerjasama dengan GenPI (Generasi Pesona Indonesia) 
Lombok Sumbawa dalam mempromosikan pariwisata NTB, dengan penyampaian secara berulang, informatif, dan membujuk wisatawan untuk datang ke NTB"

GenPI Lombok Sumbawa merupakan komunitas yang bermitra dengan Dinas Pariwisata Provinsi NTB dalam mempromosikan pariwisata NTB. GenPI adalah singkatan dari generasi pesona Indonesia yang dibentuk oleh kementerian pariwisata untuk promosi pariwisata melalui media digital/sosial media. Bentuk kerjasama dengan GenPI adalah berupa promosi melalui sosial media menggunakan akun GenPI, hingga akun para member GenPI seperti instagram, facebook, twitter, dan website GenPI Lombok Sumbawa. Koordinator GenPI Lombok Sumbawa mengatakan bahwa:

“GenPI adalah mitra Dinas Pariwisata, jadi kami bukan atasan atau bawahan dari Dinas

Pariwisata. GenPI memfokuskan promosi pariwisata pada media online, karena kami merasa efeknya akan lebih besar. Bentuk koordinasi dengan Dinas Pariwisata adalah berupa pertemuan, diskusi terkait dengan event - event, dan perkembangan pariwisata Lombok Sumbawa"

Promosi yang dilakukan GenPI adalah dengan 3 periode publikasi/promosi yaitu pre event (sebelum kegiatan), on event (saat kegiatan berlangsung), post event (setelah kegiatan) melalui sosial media. Dimana GenPI sebagai volunteer untuk mempromosikan pariwisata Lombok Sumbawa sehingga tidak berbayar, yang berbayar hanya biaya operasional seperti biaya pembuatan teaser video promosi, boosting berbayar melalui facebook/instagram. Tak hanya promosi online, GenPI turut andil dalam segi offline seperti ikut serta dalam event yang diadakan. Selain melakukan promosi, GenPI membentuk Destinasi Digital Pasar Pancingan pada akhir tahun 2017 yang merupakan binaan Kementerian Pariwisata, dan bersinergi dengan Dinas Pariwisata Provinsi NTB.

Selain melakukan promosi dan pembentukan destinasi digital, bentuk kerjasama Dinas Pariwisata Provinsi NTB dengan GenPI adalah pembuatan lomba - lomba untuk menarik minat geneasi milenial untuk ikut andil dalam promosi pariwisata NTB, seperti mengadakan lomba blog, vlog, hingga photo contest pada Pesona Ramadhan tahun 2017. GenPI berperan sebagai creator dan melakukan promosi, sedangkan Dinas Pariwisata Provinsi NTB berbeperan dalam mendukung pendanaan, dan fasilitias yang dibutuhkan oleh GenPI untuk menunjang kegiatan yang dilakukan.

Selain GenPI, Dinas Pariwisata Provinsi NTB juga melibatkan peran Pokdarwis atau kelompok sadar wisata. Pokdarwis dibentuk oleh Dinas Pariwsata untuk daerah - daerah wisata yang berperan dalam bidang destinasi pariwisata di derahnya masing - masing. Seperti menjaga kebersihan daerah wisata, pembenahan daerah wisata, dan promosi kepada masyarakat sekitar daerah wisata.

d. Government/Pemerintah

Dinas Pariwisata Provinsi NTB bekerjasama dengan Kementerian Pariwisata Indonesia, dan Dinas Pariwisata kabupaten/kota. Dimana dengan Kementerian Pariwisata Indonesia, Dinas Pariwisata Provinsi NTB berperan sebagai perpanjangan tugas dari Kementerian Pariwisata Indonesia yang 
bertanggungjawab memajukan pariwisata NTB. Bentuk kerjasama Dinas Pariwisata Provinsi NTB dengan Kementerian Pariwisata berupa penentuan event - event daerah yang layak di-publish dan dipromosikan oleh kementrian, penganggaran biaya, hingga peningkatan sarana dan prasarana daerah yang belum memiliki anggaran di daerah kabupaten/kota.

Salah satu bentuk koordinasi Dinas Pariwisata Provinsi NTB dengan Kementerian Pariwisata Indonesia adalah pelaksanaan event Pesta Rakyat Bau Nyale, Festival Pesona Tambora, Bulan Pesona Lombok Sumbawa, Festival Pesona Moyo yang diakomodir langsung oleh Kementerian Pariwisata Indonesia karena keempat event tersebut masuk di dalam event Wonderful Indonesia. Selain hal tersebut, bentuk kerjasama Dinas Pariwisata Provinsi NTB dengan Kementerian Pariwisata Indonesia adalah pada International Tourismus Borse (ITB) Berlin 2017. Dimana Dinas Pariwisata Provinsi NTB mengusung brand Friendly Lombok dengan difasilitasi oleh Kementrian Pariwisata Indonesia pada pameran tersebut, di Messe Berlin Jerman.

Sedangkan untuk kerjasama dengan Dinas Pariwisata kabupaten/kota adalah bersama sama mensinergikan program yang ada di masing -masing kabupaten/kota untuk dikemas menjadi sebuah program pariwisata/event pariwisata. Selain dengan Kementerian Pariwisata Indonesia dan Dinas Pariwisata Kabupaten/Kota, Dinas Pariwisata Provinsi NTB juga menjalin kerjasama dengan Badan Promosi Pariwisata Daerah (BPPD), yang perannya adalah untuk mempromosikan potensi pariwisata NTB dengan strategi promosi yang dimiliki oleh BPPD, namun tetap berkoordinasi dengan Dinas Pariwisata Provinsi NTB untuk mensinergikan hal - hal atau potensi yang akan dipromosikan. Dinas Pariwisata Provinsi NTB juga melakukan kerjasama dengan Dinas Perindustrian Perdagangan Provinsi NTB, dengan melakukan koordinasi terkait produk - produk hasil usaha yang dapat dipasarkan ke wisatwan, seperti produk Usaha Kecil Mengah (UKM).

Kemudian adanya kerjasama dengan beberapa pemerintah daerah di Indonesia yang tergabung dalam Mitra Praja Utama (MPU) forum kerjasama daerah. Anggota MPU terdiri dari Provinsi Nusa Tenggara Timur, Banten, Nusa Tenggara Barat, Lampung, Bali, Jawa Timur, Yogyakarta, Jawa Tengah, Jakarta, dan Jawa Barat. Bentuk kerjsama yang dilakukan adalah masing - masing daerah yang tergabung dalam MPU saling mempromosikan wisata daerah yang menjadi anggota dari MPU, seperti menukar wisatawan dari daerah masing - masing.

e. Media

Kerjasama dengan media yang dilakukan oleh Dinas Pariwisata Provinsi NTB adalah dengan merangkul media cetak dan elektronik lokal seperti Lombok Post, Suara NTB, Radar Lombok, Lombok TV dan lainnya yang tergabung dalam forum wartawan pariwisata Nusa Teggara Barat, dimana media media cetak dan elektronik tersebut berperan mempublikasikan kegiatan pariwisata, publikasi dapat bersifat informasi umum/berita, dan berbayar (kolom khusus/iklan). Kerjasama yang dilakukan bersifat 
timbal balik atau mutualisme dimana media membutuhkan berita untuk dimuat/diterbitkan di media masing - masing dan Dinas Pariwisata Provinsi NTB membutuhkan publikasi oleh media cetak dan elektronik tersebut.

Tidak hanya dengan media lokal, Dinas Pariwisata Provinsi NTB juga melakukan kerjasama dengan media nasional hingga internasional. Kerjasama dengan media nasional seperti dengan MNC grup, Transcorp, Metro TV, TVOne, berupa tayangan/siaran tunda kegiatan pariwisata, iklan dan berita. Berikut adalah bentuk kerjasama Dinas Pariwisata Provinsi NTB dengan CV. ADD-G MULTIFX GROUP, selaku penyedia layanan TV One wilayah Nusa Tenggara Barat:

1. Dinas Pariwisata Provinsi NTB sepakat dan bersedia untuk melakukan kerjasama dengan CV. ADD-G MULTIFX GROUP berupa peliputan dan penayangan paket dokumentasi di TV ONE sebanyak 1 (satu) event yaitu Festival Pesona Bau Nyale 2017 yang diadakan oleh Dinas Pariwisata Provinsi NTB dengan biaya sebesar Rp. 25.000.000,- (Dua puluh lima juta rupiah) yang telah disepakati bersama.

2. CV. ADD-G MULTIFX GROUP sepakat dan bersedia membuat dan menayangkan iklan/produk milik Dinas Pariwisata Provinsi NTB di setiap event/kegiatan yang diadakan dan yang melibatkan CV. ADD-G MULTIFX GROUP sebagai Media Partner di dalamnya.

Kemudian kerjsama dengan media majalah nasional yaitu Destinasi Indonesia, dalam bentuk majalah destinasi dengan konten promosi produk pariwisata NTB.

Dinas Pariwisata Provinsi NTB juga melakukan kerjasama dengan PT. Abadi Business Solutions (Api Magazine), dengan bentuk kerjasama sebagai berikut:

1. Dinas Pariwisata Provinsi NTB sepakat dan bersedia untuk melakukan kerjasama dengan PT. Abadi Business Solutions berupa pemuatan berita obyek dan daya tarik pariwisata, event pariwisata dalam bentuk iklan advetorial dan pencantuman Logo Pemerintah daerah, dan Logo Program Unggulan Dinas Pariwisata Provinsi NTB pada Cover Majalah API Magazine berbahasa Jepang yang diterbitkan oleh PT. Abadi Business Solutions yang dilaksanakan oleh Dinas Pariwisata Provinsi NTB.

2. PT. Abadi Business Solutions sepakat dan bersedia meliput dan memuat obyek dan daya tarik pariwisata, event pariwisata dalam bentuk iklan advetorial milik PT. Abadi Business Solutions di setiap event/kegiatan yang diadakan dan yang melibatkan Dinas Pariwisata Provinsi NTB sebagai Media Partner di dalamnya.

Kerjasama dengan media internasional yaitu Indo A Go-Go Travel \& Lifestyle Company pada tahun 2017, dengan rincian kerjasama sebagai berikut:

1. 1 (Satu ) x 4 menit pada segmen TV yang menayangkan tentang Lombok.

2. Penayangan dan promosi Branding Friendly Lombok.

3. Sosialisasi program melalui media sosial yang tidak bertentangan dengan program iklan Channel 10. 
4. Sosialisasi melalui jalur travel agent yang tidak bertentangan dengan program iklan Channel 10 seperti Helloworld dan Flight Centre.

Sesuai dengan pengertian penta helix menurut (Lindmark, Sturesson \& Roos, 2009cit.Wagiran, 2012) merupakan perluasan dari strategi triple helix dengan melibatkan berbagai unsur masyarakat maupun lembaga-lembaga non profit dalam rangka mewujudkan inovasi. Melalui kolaborasi sinergis tersebut diharapkan terwujud suatu inovasi yang didukung oleh berbagai sumberdaya yang berinteraksi secara sinergis. Dinas pariwisata Provinsi NTB melakukan kerjasama Sinergi Penta Helix dengan stakeholders untuk mewujudkan inovasi guna mencapai tujuan strategi itu sendiri, yaitu meningkatkan kunjungan wisatawan Lombok Sumbawa. Pada pelaksanaannya Sinergi Penta Helix yang dilakukan oleh Dinas Pariwisata Provinsi NTB yakni kerjasama dengan sinergi penta pelix ABCGM, yang merupakan singkatan dari Academic, Business, Community, Government, Media (KEMENPAR dalam Laporan Capaian Sektor Pariwisata 3 Tahun Jokowi - JK). Dinas Pariwisata Provinsi NTB memiliki kerjasama dengan masing - masing stakeholders ABCGM untuk membentuk program, paket wisata, hingga promosi. Dilaksanakannya kerjasama Sinergi Penta Helix tersebut, Dinas Pariwisata Provinsi NTB dapat meningkatkan kunjungan wisatawan Lombok Sumbawa tahun 2016 - 2017. Hal tersebut pun sesuai dengan Von Stamm (2004) cit. Halibas (2017) menyatakan bahwa inovasi sangat dicapai ketika adanya kolaborasi yang kuat dan kerjasama diantara orang penting.

\section{Event}

Selain menjalin kerjasama pariwisata, Dinas Pariwisata Provinsi NTB telah melaksanakan event pariwisata yang dilakukan untuk menjadi daya tarik pariwisata dalam meningkatkan kunjungan wisatawan. Event - event yang dilakukan Dinas Pariwisata Provinsi NTB bertujuan untuk meningkatkan kunjungan wisatawan Lombok Sumbawa dengan menyuguhkan berbagai macam atraksi budaya, keindahan alam, olahraga, industri kreatif, hingga kuliner yang dimiliki oleh Nusa Tenggara Barat.

Event - event yang diadakan dapat meningkatkan kunjungan wisatawan, terlihat dari keramaian yang terjadi dalam event - event pariwisata yang diadakan oleh Dinas Pariwisata Provinsi NTB. Event dihadiri oleh wisatawan dari berbagai daerah, baik wisatawan nusantara maupun wisatawan mancanegara. Berdasarkan hasil observasi yang dilakukan di Dinas Pariwisata Provinsi NTB, catatan kunjungan perevent tidak ditemukan secara lengkap, hanya ditemukan 2 laporan yang menggambarkan catatan event yang sudah dilaksanakan. Seperti data yang

41

pada laporan event International Halal Travel Fair yakni sebanyak 220 buyers, yang berasal dari buyers domestik dan mancanegara seperti India, Malaysia, Brunei Darussalam dan Australia. Dalam laporan event Grand Fondo New York (GFNY) juga tercatat sebanyak 800 peserta mengikuti ajang GFNY yang berasal dari 32 Negara. 
Pelaksanaan event secara teknis diakomodir oleh Event Organizer yang memenangkan tender pada setiap event. Namun berdasarkan hasil observasi pada bagian pemasaran di Dinas Pariwisata Provinsi NTB, tidak ditemukan data terkait list nama event organizer yang mengakomodir event yang telah dilaksanakan.

Sasaran dari event yang diadakan sangat beragam, bahkan dapat dikatakan sangat multi. Karena event diadakan untuk menarik perhatian wisatawan, baik wisatawan nusantara maupun wisatawan mancanegara. Kepala Seksi Analisa Pasar Dinas Pariwisata Provinsi NTB mengatakan bahwa:

“Target pasar NTB sangat multi, karena memiliki potensi alam, budaya, dan minat khusus, yang tentunya mudah diterima oleh hampir semua suku bangsa. Tentunya Dinas Pariwisata Provinsi NTB juga mengukur efektifitas dari marketing yang dilakukan, contohnya ketika Dinas Pariwisata Provinsi NTB ingin menggiring pasar wisatawan Nusantara, Dinas Pariwisata Provinsi NTB menentukan konektivitas yang sudah tersedia di daerah tersebut, misalnya untuk daerah Nusantara yaitu 5 kota besar seperti Jakarta, Yogyakarta, Bali, Surabaya, dan Makasar yang diklasifikasikan menjadi kantong - kantong penyebaran wisatawan di Indonesia yang cukup berpeluang, karena pada kota - kota besar tersebut banyak penerbangan langsung ke Lombok, NTB. Sedangkan untuk mancanegara, mulai dari daerah ASEAN seperti Malaysia, Singapore, kemudian Australia, Timur Tengah, dan banyak Negara lainnya. Namun tetap melihat prospek dari masing - masing Negara.Pemetaan khalayak dilakukan untuk lebih mengenal wisatawan, yakni kecenderungan mereka terhadap wisata yang dituju."

Event yang dilakukan oleh Dinas Pariwisata Provinsi NTB tahun 2016 - 2017 sangat beragam dan menarik perhatian wisatawan. Terbukti dengan meningkatnya kunjugan wisatawan selama 2 tahun tersebut, tentu tidak lepas dari adanya daya tarik dari event - event tersebut. Dimana tujuan diadakan event tersebut adalah untuk meningkatkan kunjugan wisatawan Lombok Sumbawa tahun 2016 - 2017.

Hal ini pun sesuai dan sejalan dengan pengertian event itu sendiri, yaitu Event dalam arti sempit diartikan sebagai pameran, pertunjukan atau festival, dengan syarat ada penyelenggara, peserta dan pengunjung. Namun dalam arti luas, event diartikan sebagai suatu kurun waktu kegiatan yang dilakukan oleh sebuah organisasi dengan mendatangkan orang - orang ke suatu tempat agar mereka memperoleh informasi atau pengalaman penting serta tujuan lain yang diharapkan oleh penyelenggara (Kennedy, 2009 cit. Rahma, 2017).

Berdasarkan teori dan pelaksanaan yang dilakukan oleh Dinas Pariwisata Provinsi NTB, event merupakan salah satu rangkaian kegiatan dari strategi komunikasi yang mampu meningkatkan kunjungan wisatawan Lombok Sumbawa tahun 2016 - 2017, terbukti dengan meningkatnya kunjungan wisatawan Lombok Sumbawa yaitu 3.094.437 wisatawan pada tahun 2016, dan 3.500.000 wisatawan pada tahun 2017. 


\section{Promosi}

Promosi merupakan salah satu strategi yang telah dilakukan oleh Dinas Pariwisata Provinsi NTB dalam meningkatkan kunjungan wisatawan Lombok Sumbawa pada tahun 2016 - 2017. Promosi yang dilakukan oleh Dinas Pariwisata Provinsi NTB tahun 2016 - 2017 yaitu dengan memaksimalkan pada penggunaan media promosi. Kepala Seksi Analisa Pasar mengungkapkan bahwa:

"Selama 2016 - 2017 bahkan hingga saat ini yang paling efektif adalah promosi melalui sosial media, oleh karena itu koordinasi atau kerjasama dengan GenPI sanagat penting. Disamping itu Dispar mengadakan event - event pariwisata untuk menarik kunjungan wisatawan, yang kemudian dipromosikan kembali melalui sosial media, cetak, dan elektronik. penggunaan media cetak biasanya berupa baliho, poster, dan sebagainya, sedangkan untuk media elektornik yaitu website, iklan di TV Nasional (masih terbilang cukup jarang), dan penayangan iklan di TV maskapai. Namun sejauh ini penggunaan yang digencarkan masih melalui sosial media"

Media promosi yang digunakan oleh Dinas Pariwisata Provinsi NTB dalam menyampaikan pesan kepada khalayak dikenal dengan sebutan POSE. POSE adalah singkatan dari beberapa jenis media yang digunakan yaitu Paid Media, Owned Media, Social Media, dan Endorser yang digunakan sebagai media promosi pariwisata. Berikut adalah promosi yang dilakukan oleh Dinas Pariwisata Provinsi NTB, sesuai dengan jenis medianya:

\section{a. Paid Media}

Paid media adalah media berbayar untuk memasang iklan pada space media tertentu. Paid Media yang digunakan oleh Dinas Pariwisata Provinsi NTB berupa baliho, brosur, umbul - umbul, iklan koran lokal (Lombok Post, Suara NTB, Radar Lombok), beberapa inflight magazine seperti inflight magazine Garuda Indonesia, Citilink dan Lion Air, chanel TV lokal Lombok TV, hingga chanel TV Nasional seperti Trans TV dan Trans7, dan beberapa chanel TV Nasional lainnya.

Selain itu Dinas Pariwisata Provinsi NTB juga menggunakan paid media berupa pemasangan branding Pesona Lombok Sumbawa di Taxi All Bos Executive Malaysia jenis Inova sebanyak 4 (empat) buah, pada bulan Maret 2016. Pelaksanaan kegiatan Promosi melalui pemasangan Branding Pesona Lombok Sumbawa pada Mobil Branding diresmikan di Twin Tower Kuala Lumpur Malaysia 2016, bersamaan dengan kegiatan MATTA Travel fair yang merupakan ajang promosi antar buyyer dan seller dari seluruh kawasan Asia khususnya negara-negera anggota ASEAN pada bidang kepariwisataan. Penggunaan mobil sebagai media branding (vehicle wrap) yaitu salah satu media promosi, sticker vinyl yang di cetak dengan digital printing dan di aplikasikan pada kendaraan seperti minibus, mobil box, mobil niaga, bus, angkutan umum, sampai sepeda motor.

Penggunaan vehicle wrap juga digunakan pada pemasangan branding Pesona Lombok Sumbawa di Bus Trans Jakarta 2016. Pelaksanaan kegiatan promosi melalui pemasangan Branding Pesona Lombok 
Sumbawa pada Bus Trans Jakarta 2016 dilakukan di Koridor I dan II, dengan tujuan untuk menyebarkan informasi tentang Lombok Sumbawa sebagai salah satu destinasi unggulan yang layak dikunjungi oleh wisatawan baik domestik maupun mancanegara.

\section{b. Owned Media}

Owned Media adalah media dimiliki oleh Dinas Pariwisata Provinsi NTB itu sendiri, atau dikelola oleh Dinas Pariwisata Provinsi NTB. Owned Media yang digunakan oleh Dinas Pariwisata Provinsi NTB adalah website http://www.disbudpar.ntbprov.go.id/, dan majalah Pesona Lombok Sumbawa. Owned Media juga merupakan bentuk dari direct sell atau promosi secara langsung yang dilakukan oleh Dinas Pariwisata Provinsi NTB kepada publik.

Majalah Pesona Lombok Sumbawa diterbitkan setiap 1 bulan sekali. Namun pada pelaksanaannya Majalah tersebut terakhir diterbitkan pada Desember 2016. Sedangkan pada tahun 2017 sudah tidak diterbitkan, karena pada tahun 2017 tidak ada anggaran untuk Majalah Pesona Lombok Sumbawa. Konten Majalah Pesona Lombok Sumbawa terdiri dari Pesona Utama, Pesona Destinasi, Pesona Budaya, Pesona Promosi, Pesona Sport Tourism, Pesona Inspirasi, dan Pesona Akomodasi. Majalah Pesona Lombok Sumbawa dibagikan secara percuma kepada wisatawan pada saat event, seminar, atau kegiatan serupa.

Website Dinas Pariwisata Provinsi NTB memiliki rata - rata kunjungan lebih dari 1 Juta kunjungan per tahun. Hal tersebut juga sesuai dengan perhitungan pada situs statshow.com (situs untuk melihat nilai website secara gratis). Jika dilihat melalui pencarian google, website Dinas Pariwisata Provinsi NTB juga berada di urutan teratas.

\section{c. Social Media}

Social Media yang digunakan oleh Dinas Pariwisata Provinsi NTB dalam mempromosikan pariwisata NTB, yaitu instagram, facebook, dan twitter. Pada instagram @disparntb, update yang dilakukan adalah dengan repost konten, iklan/promosi event dan lomba, promosi destinasi Lombok Sumbawa. Sedangkan pada twitter @ disbudpar_ntb berisi tentang berita kegiatan pariwisata. Kemudian pada fanpage @Informasi.Pariwisata.Lombok.Sumbawa berisi tentang terusan berita pariwisata dari website Dinas Pariwisata Provinsi NTB.

Berdasarkan hasil observasi ke Dinas Pariwisata Provinsi NTB, belum ada waktu tertentu dalam memposting konten pada setiap sosial media. Update dilakukan ketika ada kegiatan pariwisata, dan repost dilakukan jika ada konten yang ditandai menarik untuk menjadi daya tarik promosi pariwisata bagi wisatawan.

d. Endorser

Cara promosi melalui media ini adalah dengan melibatkan public figure di dalamnya, dengan mengiklankan pariwisata NTB seperti memberikan terlibat dalam kegiatan pariwisata, testimony maupun 
review tentang pariwisata NTB pada akun pribadi public figure, sesuai dengan kesepakatan. Pada hasil wawancara dengan Kepala Seksi Analisa Pasar, Dinas Pariwisata Provinsi NTB belum pernah menggunakan endorser. Namun pada fakta yang ditemukan berdasarkan hasil dokumentasi dan observasi, selama tahun 2016 - 2017 Dinas Pariwisata Provinsi NTB pernah menggunakan endorser, yaitu melibatkan Gubernur NTB, Tuan guru Bajang (TGB) untuk ikut serta dalam event GFNY, dan Tour De Lombok. Kemudian mengikut sertakan pelari ekstrem Hendra Wijaya dalam event Rinjani 100.

“Untuk endorse Dinas Pariwisata Provinsi NTB belum pernah menggunakan endorse, namun dari vendor/Event Organizer yang mengadakan atau mengeksekusievent - event, kerap mengundang artis artis atau public figure untuk menarik hati wisatawan"

Promosi tentu erat kaitannya dengan media, di mana media merupakan saluran untuk menyampaikan pesan dari promosi yang dilakukan. Media sangat diperlukan, karena media merupakan saluran komunikasi dalam menyebarluaskan pesan yang ingin disampaikan. Penggunaan media merupakan bagian dari strategi komunikasi Dinas Pariwisata Provinsi NTB dalam melakukan promosi berbagai macam program, atau pesan yang ingin disampaikan kepada khalayak. Sesuai dengan pengertian promosi yaitu kegiatan yang dilakukan untuk memperkenalkan barang/ jasa agar konsumen tertarik untuk membelinya (Kotler, 2013 cit. Lestari 2016), yang dalam hal ini objek yang dipromosikan adalah produk pariwisata Lombok Sumbawa, sehingga penting untuk menggunakan media yang tepat dalam hal tersebut.

Media yang digunakan oleh Dinas Pariwisata Provinsi NTB dalam menyampaikan pesan dan mempromosikan produk wisatanya adalah Paid Media atau media berbayar seperti baliho, umbul, iklan koran, inflight magazine, iklan tv, dan Vehicle wrap.

Selanjutnya penggunaan Owned Media yaitu media yang dimiliki oleh Dinas Pariwisata Provinsi NTB seperti website, dan majalah. Kemudian Social Media seperti instagram, facebook, dan twitter. Melibatkan public figure yaitu TGB dan Hendra Wijaya dalam kegiatan pariwisata untuk menarik daya tarik wisatawan.

Memperhatikan serangkaian kegiatan diatas, yaitu kerjasama sinergi pentahelix, event, dan promosi, ketiganya akan saling terkait dalam sebuah strategi komunikasi yang dilakukan oleh Dinas Pariwisata Provinsi NTB. Strategi komunikasi yang dilakukan oleh Dinas Pariwisata Provinsi NTB yaitu dengan melakukan kerjasama sinergi pentahelix, mengadakan event pariwisata, dan promosi pariwisata mampu meningkatkan kunjungan wisatawan Lombok Sumbawa yaitu sebanyak 3.094.437 (1.690.109 wisatawan nusantara, 1.404.328 wisatawan mancanegara) pada tahun 2016, dan 3.508.903 (2.078.654 wisatawan nusantara, dan 1.430.249 wisatawan mancanegara) pada tahun 2017.

\section{Kesimpulan dan Saran}

Dinas Pariwisata Provinsi NTB memiliki strategi komunikasi yang digunakan untuk meningkatkan kunjungan wisatawan Lombok Sumbawa tahun 2016 - 2017. Strategi komunikasi yang dilaksanakan 
oleh Dinas Pariwisata Provinsi NTB yang terdiri dari 3 rangkaian kegiatan, yaitu (1) Sinergi Penta Helix, (2) Event pariwisata, dan (3) Promosi.

Sinergi Penta Helix dilakukan dengan para stakeholders ABCGM (Akademisi, Business, Community, Government, dan Media) dimana kerjasama tersebut dilakukan sesuai dengan fungsi dan bagian masing - masing stakeholders yang saling bersinergi untuk meningkatkan kunjungan wisatawan Lombok Sumbawa tahun 2016 - 2017. Kemudian dengan mengadakan event pariwisata, terdapat 12 event pada tahun 2016 dan 22 event pada tahun 2017 yang dilaksanakan guna menjadi daya tarik bagi wisatawan, sehingga dapat meningkatkan kunjungan wisatawan Lombok Sumbawa tahun 2016 - 2017. Selanjutnya adalah dengan promosi melalui media, yaitu mempromosikan kegiatan - kegiatan pariwisata NTB. Dimana konsep promosi yang dilakukan oleh Dinas Pariwisata Provinsi NTB adalah dengan menggunakan POSE (Paid Media, Owned Media, Social Media, dan Endorse).

Ketiga kegiatan tersebut saling bersinergi dan terkait menjadi sebuah strategi komunikasi, sehingga tujuan peningkatan kunjungan wisatawan Lombok Sumbawa tahun 2016 - 2017 dapat tercapai yaitu sebanyak 3.094.437 (1.690.109 wisatawan nusantara, 1.404 .328 wisatawan mancanegara) pada tahun 2016, dan 3.508.903 (2.078.654 wisatawan nusantara, dan 1.430.249 wisatawan mancanegara) pada tahun 2017.

\section{Saran}

Peneliti memberikan beberapa saran untuk Dinas Pariwisata Provinsi NTB, antara lain:

1. Berdasarkan hasil penelitian yang dilakukan, Dinas Pariwisata Provinsi NTB sedikit melakukan kerjasama dengan akademisi dalam hal riset tentang pariwisata. Oleh karena itu Dinas Pariwisata Provinsi NTB sebaiknya memperbanyak kerjasama dengan para akademisi dalam membuat sebuah riset atau kajian ilmu tentang pariwisata NTB, yang nantinya hasil riset dapat bermanfaat untuk kemajuan pariwisata NTB.

2. Berdasarkan hasil penelitian yang dilakukan, Dinas Pariwisata Provinsi NTB sebaiknya memaksimalkan promosi melalui owned media, dengan melakukan update pada owned media Dinas Pariwisata Provinsi NTB, baik dari desain, maupun konten. Pada social media Dinas Pariwisata juga sebaiknya memaksimalkan penggunaan sosial media, yaitu dengan menggunakan id yang sama pada setiap sosial media, agar mempermudah khalayak untuk mencari informasi seputar pariwisata NTB melalui official account social media Dinas Pariwisata Provinsi NTB. 
3. Berdasarkan hasil penelitian yang dilakukan, Dinas Pariwisata Provinsi NTB sebaiknya memaksimalkan konsep promosi POSE yang telah digunakan, dengan memaksimalkan keterlibatan public figure sebagai media endorser atau brand ambassador.

\section{Referensi}

Ambar.2017. Teori Strategi Komunikasi - Pengertian -

Landasan.https://pakarkomunikasi.com/teori-strategi-komunikasi . [10 November 2017]

Ashdiana, I Made. 2017. Kemenpar Inginkan Lombok Jadi Tujuan Wisatawan Korea. Kompas.com. Travel.

http://travel.kompas.com/read/2017/01/12/205100027/kemenpar.inginkan.lombok.jadi.tujuan.utama. wisatawan.korea. [15 November 2017]

Cangara, 2011.Pengantar Ilmu Komunikasi, PT RajaGrafindo Persarda: Jakarta.

David, Fred R. 2002. Manajemen Strategi Konsep. Prenhalindo: Jakarta

Dinas Kebudayaan dan Pariwisata NTB.2016.Statistik Kebudayaan dan Pariwisata Provinsi Nusa

Tenggara Barat2016.Dinas Kebudayaan dan Pariwisata NTB. Mataram

Dinas Pariwisata NTB. 2017. Kajian Analisa Pasar Potensial Nusa Tenggara Barat Tahun

2017.Dinas Pariwisata NTB. Mataram

Effendy, Onong Uchjana. 2007. Komunikasi Teori dan Praktek. PT Remaja Rosdakarya: Jakarta. --------. 2004. Dinamika Komunikasi. PT Remaja Rosdakarya. Jakarta.

Efrita, Neni. 2015. Strategi Komunikasi Pengembagan Pariwisata. Imam Bonjol Press. Sumatra

Barat.

Halibas, Alrence Santiago., Rowena Ocier Sibayan, Rolou Lyn Rodriguez Maata. 2017. The Penta Helix Model of Innovation in Oman: an HEI Perspective. Interdisciplinary Journal of Information, Knowledge, and Management.vol. 12

Kementrian Pariwisata. 2016. Siaran Pers Menteri Pariwisata Berikan Penghargaan Anugerah Pariwisata Halal Terbaik 2016.http://www.kemenpar.go.id/asp/detil.asp? $c=16 \& i d=3333$. [23 Januari 2018]

Kementrian Pariwisata. 2017. Laporan Capaian Sektor Pariwisata 3 Tahun Jokowi - JK. http://presidenri.go.id/wp-content/uploads/2017/10/KEMENPAR-Laporan-3-Th-Jkw-JK.pdf. [11 Juli 2018]

Lestari, Sinta Petri. 2015. Hubungan Komunikasi Pemasaran dan Promosi dengan Keputusan Memilih Jasa Layanan Kesehatan (Studi pada Rumah Sakit Islam Lumajang).Interaksi 4: 139 - 147. Mahrik, Ardilla. 2016. Strategi Komunikasi Dinas Komunikasi Informatika Kebudayaan dan Kepariwisataan dalam Meningkatkan Kunjungan Wisatawan di Kabupaten Sinjai. [Skripsi S1, unpublish]. Jurusan Ilmu Komunikasi, Fakultas Ilmu Sosial dan Politik, Universitas Hasanuddin. Sulawesi Selatan.Indonesia Meidila, Meriska. 2014. Aktivitas Promosi Dinas Kebudayaan dan Pariwisata Kabupaten Wakatobi dalam Meningkatkan Kunjungan Wisata Wakatobi Sulawesi Tenggara. [Skripsi S1, unpublised]. Jurusan Ilmu Komunikasi, Fakultas Ilmu Sosial dan Politik, Universitas Hasanuddin. Sulawesi Selatan.Indonesia.

Mustafa, Ardita. 2017. Bali Kalahkan Paris Sebagai Destinasi Terbaik Dunia. CNN Indonesia. Berita Wisatahttps://www.cnnIndonesia.com/gaya-hidup/20170323134114-269-202253/bali-kalahkanparis-sebagai-destinasi-terbaik-dunia/.[10 Novemeber 2017]

Nur, Muhammad. 2017. Pariwisata Dongkrak Pertumbuhan Ekonomi NTB. https://www.jawapos.com/read/2017/08/08/149477/pariwisata-dongkrak-pertumbuhan-ekonomiNTB. [19 Desember 2017] 
Nursyamsi, Muhammad. 2017. NTB Lampaui Target Jumlah Wisatawan 2017.

Republika.Leisure.http://www.republika.co.id/berita/gaya-hidup/travelling/17/12/29/p1pvws284NTB-lampaui-target-jumlah-wisatawan-2017.[ 23 Januari 2017]

Priansa, Donni Juni. 2017. Komunikasi Pemasaran Terpadu (Pada Era Media Sosial).CV Pustaka Setia. Bandung.

Rahkmat, Jalaluddin. 2012. Metode Penelitian Komunikasi. PT Remaja Rodakarya. Bandung. Rahma, Ade. 2017. Event Sebagai Salah Satu Bentuk Strategi Komunikasi Pemasaran Produk Fashion Nasional (Event Tahunan Jakcloth). Journal of Communication (Nyimak). Vol 1 No 2 Redaksi Kicknews. 2017. Kemenpar Ingin Lombok Jadi Tujuan Wisatawan

Korea.Kicknews.today.Pariwisata.https://kicknews.today/2017/01/13/23663/. [10 November 2017] Riadi, Muchlisin. 2016. Pengertian, Tujuan dan Bauran Komunikasi.

http://www.kajianpustaka.com/2016/11/pengertian-tujuan-dan-bauran-promosi.html. [28 Desember 2017]

Septia, Karnia. 2017. Menpar: Lombok Disiapkan Jadi Destinasi Utama Pariwisata. Kompas.com. Travel.

http://travel.kompas.com/read/2016/03/18/143600227/Menpar.Lombok.Disiapkan.Jadi.Destinasi.Ut ama.Pariwisata. [12 November 2017] 